\title{
Teaching Reading through WebQuest
}

\author{
Luu Trong Tuan \\ National University of Ho Chi Minh City, Vietnam \\ Email: luutrongtuan@vnn.vn
}

\begin{abstract}
The research seeks to examine if the implementation of WebQuest helps enhance reading skill, and to explore the students' attitude towards WebQuest-based teaching of reading. Through the action research, the findings display that the students who received the WebQuest-based program made considerable improvement in their reading. The findings were also enhanced by the positive feedback of the students towards the use of WebQuest through the online survey carried out after the course.
\end{abstract}

Index Terms - reading, WebQuest, action research, English as a foreign language (EFL)

\section{INTRODUCTION}

The current globalization of economy and the continuing increase in international communication in various fields have resulted in greater demand for English as a foreign language (EFL). Among all the four skills integrated in English curriculum, reading skill tends to be the priority in the English curricula at universities throughout the country. Reading authentic materials is of great importance for those who have the desire for further study and for their future careers as it is one of the best ways to improve their English as well as understand and use the information in up-to-date sources in their respective fields of study.

To develop reading, one of the most useful resources is the Internet, with a large amount of varied and easily accessible authentic materials. One of the main reasons for using authentic materials in the classroom is that the controlled language learning environment, the learner will encounter the real world and the real language. The role of the teacher is not to delude the language learner but to prepare him necessary skills so as to understand how the language is actually used.

There is no denying that the scene of education is changing briskly and significantly. Educators are trying to keep up with new developments which results in the change. Nowadays, in the era of information, EFL teachers use computers and the Internet more and more frequently to facilitate teaching and enhance the learning experience. The Internet is blooming into a huge source of information which can be freely and easily accessed by both students and teachers. Charupan, Soranastaporn, and Suwattananand (2001) believed that technology can be used to facilitate classroom instruction. The Internet is a learning tool that fits well in a content-based English syllabus. Among the benefits of Internet use in the second and foreign language classroom, the most important are: Increased motivation and participation by students (Warschauer, 1996); more opportunities to interact with the target language and content area because students spend more time on task (Kasper, 2000); greater integration of reading and writing skills and opportunities to practice them in meaningful contexts; the possibility to implement a pedagogy based on problem solving and critical thinking (Warschauer, 1999); more self-paced autonomous learning that is learner-controlled rather than teacher-controlled. (Mak, 1995).

Furthermore, the Internet provides the resources necessary to carry out authentic projects and analysis, and thus develops the communicative competence of EFL students. Such resources allow teachers to design simulation activities and role-playing using authentic material. Kimball (1997) pointed out that "Internet-generated materials can be flexibly arrayed to engage students with topics and cognitive tasks relevant to students' professional futures." Furthermore, the Internet-based activities can take advantage of integrated teaching approaches. Collaborative and cooperative learning occurs when computer-assisted language learning (CALL) is used in language teaching and learning, (McCabe, 1998). Learners use websites on the Internet to perform cooperative tasks with their peers to complete work assigned by the instructor. It is the learning and teaching on the Internet that enables the learner-centred approach (Kumari, 1998). Alexander and Elena (2005, p. 129) also claimed that "the Internet helps to make English lessons more rewarding and encourages opening the new way to bring about creativity and enthusiasm for learning".

Another reason for the study was Krashen's Input Hypothesis and Frank Smith's slogan "learn to read by reading", from which extensive reading approach was developed and has been widely applauded.

The study seeks to investigate the employment of WebQuest in the teaching of reading to EFL learners by answering the ensuing research questions:

1. Does the utilization of WebQuest help improve EFL learners' reading skill?

2. What are EFL learners' attitudes towards WebQuest-based teaching of reading?

\section{LITERATURE REVIEW}




\section{A. Intensive Reading (IR) and Extensive Reading (ER)}

Intensive reading and extensive reading are two major approaches that have been used to develop reading skill. The two approaches have their advantages to offer different stages of reading instruction. In this research, WebQuest is used to teach reading, which involves intensive reading and extensive reading. An overview of the intensive reading and extensive reading is thus required.

\section{Intensive Reading (IR)}

Intensive reading is commonly considered 'text-based or skill-based' reading. The work of Palmer (1921) notes that "intensive reading" means that the readers take a text, study it line by line, and refer at very moment to the dictionary about the grammar of the text itself, or Haarman et al.(1988) describes intensive reading as "the style we employ when we wish to have a very clear and complete understanding of the written text". Similarly, intensive reading is pointed out as "reading a passage or a book slowly and carefully, paying attention to each word and every idea"(Phirie, Tsimanyana, and Masendu, 2000, pp. 31-32). Nuttall(1996, p. 38) claims that "intensive reading involves approaching the text under guidance of a teacher or a task which forces the student to focus on the text".

Intensive reading activities include skimming a text for specific information to answer true or false statements or filling gaps in a summary, scanning a text to match headings to paragraphs, and scanning jumbled paragraphs and then reading them carefully to put them into the correct order. The intensive reading intentionally focuses on essential vocabulary, patterns of text organization and types of text processing needed to adequately comprehend any text. Thus, in intensive reading, students are supposed to comprehend as fully as possible the text which is chosen by the instructor or in the reading course. Intensive reading deals with comprehension mostly at lexical and syntactic level. According to Paran (2003, p. 40), intensive reading is needed for four main reasons: to help learners comprehend written texts, to become more aware of text organization to better comprehend, to learn how to use and monitor effective reading strategies, and to develop literacy skills necessary to generate productive expressions in L2.

Bruce (2004, p. 175) believes that fundamentally, intensive reading involves translation as stating "The readers may pause to look up words in a dictionary. The reader may also mentally or even physically translate the sentence into the reader's first language (L1) by writing down the translation of words, or speaking the translated sentence aloud."

\section{Extensive Reading (ER)}

It is the view of Palmer (1964) that extensive reading is considered as rapid reading. The attention is paid to the meaning of the text itself not the language. Hafiz and Tudor (1989) deemed extensive reading to be "the reading of large amounts of material in the second language over time for personal pleasure or interest, and without addition of productive tasks or follow up language work". The purpose of extensive reading is for pleasure and information. Thus, extensive reading is also termed as "supplementary reading". Grabe and Stoller (2002) defines extensive reading as an "approach to teaching and learning in which learners read large quantities of materials that is within their linguistic competence" (ibid., p. 259). Bamford (2000) discovers that a good number of extensive reading programs use simplified books or in other words grade readers as the basic reading materials.

Day and Bamford (1998, pp. 6-8) lists key characteristics of a successful extensive reading program:

- Students read large amounts of printed material;

- Students read a variety of materials in terms of topic and genre;

- The material students read is within their level of comprehension;

- Students choose what they want to read;

- Reading is its own reward;

- Students read for pleasure, information and general understanding;

- Students read their selection at a faster rate;

- Reading is individual (students read on their own);

- Teachers read with their students, thus serving as role models of good readers;

- Teachers guide and keep track of student progress.

Welch (1997) recapitulates characteristics of extensive reading and intensive reading displayed in the Table 1.

TABLE 1.

CHARACTERISTICS OF INTENSIVE READING AND EXTENSIVE READING

\begin{tabular}{lll} 
& CHARACTERISTICS OF INTENSIVE READING AND EXTENSIVE READING \\
\hline Reading approach & Intensive reading & Extensive reading \\
\hline Purpose & language study and accuracy & general understanding and enjoyment and fluency \\
Level & Often difficult & easy (grade readers) \\
Amount & Not much & a lot \\
Speed & slow and accuracy & fast and fluency \\
Selection & teacher selects & learner selects \\
What material & all learners study the same material & all learners read different things which interest them \\
Where & In class & mostly at home \\
Comprehension & check by specific questions and exercises & checked by reports/summaries \\
\hline
\end{tabular}

After making a comparison between these two reading approaches, Palmer (1921/1964) also concludes that both types of the reading are important because the main goal of reading is to comprehend the printed pages. 


\section{B. WebQuest}

This section presents definitions of WebQuest and its pedagogical base.

What is WebQuest?

Bernie Dodge - an American professor of educational technology at San Diego State University has focused on the design, implementation and evaluation of computer-based learning environments and created a learning model which has been widely used as an effective Internet-based educational tool in schools, colleges and universities for over a decade and is now one of the most popular and most effective Internet-based project models/ approaches. This approach clearly describes the process of the partly online learning experience which challenges, motivates and engages learners.

In an early article about this method, Bernie Dodge defined a WebQuest as:

An inquiry-oriented activity in which most of all of the information used by learners is drawn from the Web. Web quests are designed to use learners' time well, to focus on using information rather than looking for it, and to support learners' thinking and levels of analysis, synthesis, and evaluation (Dodge, 2001).

Educators thought that the original definition was not enough to cover the meaning and theoretical underpinnings of the WebQuest concept. March (2008), a co-creator of WebQuest, therefore conceptualized and expanded the definition of WebQuest:

A WebQuest is a scaffold learning structure that uses links to essential resources on the World Wide Web and an authentic task to motivate students' investigation of a central, open-ended question, development of individual expertise and participation in a final group process that attempts to transform newly acquired information into a more sophisticated understanding. The best WebQuests do this in a way that inspires students to see richer thematic relationships, facilitate a contribution to the real world of learning and reflect on their own metacognitive processes.

In a WebQuest, learners work in groups, where members have to analyze and master a particular aspect of an issue. Each member becomes an 'expert' in their role, and later contributes to an in-depth understanding of the given aspect of the final group task.

\section{Pedagogical approaches underlying WebQuest}

A WebQuest combines the benefits of the constructivist approach, inquiry-based learning approach, project-based approach, and content-based language learning.

\section{Constructivist approach}

WebQuests emerge among the several technological tools available as an example of a powerful means for supporting the principles of constructivism (Matusevich, 1995; March, 2008) in language teaching.

A WebQuest is in fact a constructivist lesson format. Mary (1998) stated constructivism as 'both a philosophy and a theory of learning'. By changing the focus of the classroom from teacher dominated to student-centered using a constructivist approach we could yield positive results. A major theme in the theoretical framework of Bruner (1990) is that learning is an active process in which learners construct new ideas or concepts based upon their current or past knowledge. The key concept of this approach is that learning is an active process of creating rather than acquiring knowledge. When Internet technology is integrated into the course curriculum, students are enabled to learn by constructing their perceptions of complex concepts (Watson, 1999). Using WebQuest, learners have to activate the mental processing which results in understanding and the creation of meaning from their own experiences (Grant, 2002). It is the constructivist learning approach and the profound influence of technology on education that require the utilization of authentic activities to give the learning situation a purpose and meaning (Reeves et al., 2002; Matejka, 2004; Baccarini, 2004). If technology is used effectively as a tool for creative work, students can be more autonomous, collaborative and reflective than in classroom without the utilization of technology.

Inquiry-based learning

Pérez Torres (2005) believes: "a WebQuest for teaching and learning a second language is an inquiry oriented activity placed in a relevant thematic context, in which the development of the task implies using web resources and developing high order thinking processes in a collaborative environment. At the same time, it provides the students the opportunity to learn and put into practice some linguistic skills, supported by a set of linguistic and procedural scaffolding."

The process of inquiring commences with gathering information and data through applying the human senses. In fact, memorizing facts and information is not the most crucial skill in today's world as facts change, and information is easily accessible by modern technology. Inquiry is seeking appropriate resolutions to questions and issues rather than seeking the right answer merely. Teachers therefore should develop their student's inquiry skills and nurture the attitude of seeking information and to encourage and enable individuals to continue the quest for knowledge throughout life. As an old adage states, "Tell me and I forget, show me and I remember, involve me and I understand." The last part of of this statement is the essence of inquiry-based learning.

Project-based learning (PBL)

Project-based learning is an instructional student-centered educational approach in which students work in teams to explore real-world problems and create presentations to share what they have learned. (Warschauer et al., 2000).

Project-based learning first began in 1918 with an article called "The Project Method" by Kilpatrick. Although Kilpatrick was influenced by John Dewey who advocated that schools should reflect society, in the late 1800s, he was 
more interested in group learning than in the cognitive development that resulted from it. More recently, brain research has shown that project-based learning works by "helping move students beyond surface learning, beyond learning held in short-term memory, learned for the test and then dropped... because the learner sees the information as important to him" (Autodesk Foundation, 1998).

The following can be seen as reasons for using Internet-based projects in the classroom:

1. There are a structured way for teachers to incorporate the Internet into the language classroom, on both a short-term and a long-term basis. No specialist technical knowledge is needed either to produce or to use Internet-based projects. However, it is certainly looking around on the Internet to see if something appropriate already exists before sitting down to create your own project.

2. More often than not, they are group activities and, as a result, lend themselves to communication and the sharing of knowledge, two principal goals of language teaching itself. The use of projects encourages cooperative learning and therefore stimulates interaction.

3. They can be used simply for language learning purposes, but can also be interdisciplinary, allowing for cross-over into other departments and subject areas. This can often give them a more 'real-world' look and feel, and provide greater motivation for the learner.

4. They encourage critical thinking skills. Learners are not required to simply regurgitate information they find, but have to transform that information in order to achieve a given task. (Dudeney and Hockly, 2007, p. 44)

Compared with learning solely from textbooks, this approach has many benefits for students, encompassing:

- Deeper knowledge of subject matter;

- Increased self-direction and motivation;

- Improved research and problem-solving skills. Blasszauer (2003)

However, those benefits are merely enhanced when technology is used in a meaningful way in the projects. Blasszauer (2003) also stated that using project-based learning, students can acquire lifelong learning skills which include the ability to find and use appropriate learning resources. The process used in project-based learning is as follows:

- Students are presented with a problem (case, research paper, video tape, for example). In groups they organize their ideas and previous knowledge related to the problem, and attempts to define the broad nature of the problem.

- Throughout discussion, students pose questions on aspects of the problem that they do not understand.

- Students see during the project-based learning that learning is an ongoing process, and that there will always be (even for the teacher) new angles, perspectives, problems to be explored.

Dudeney and Hockly (2007) also notes that in order to prepare for Internet-based project work, you will need to do the following:

- Choose the project topic

- Make the task clear

- Find the resources

- Decide on the outcome

Content-based language learning

Content-based learning is a kind of teaching/learning process organization in which the focus of instruction is shifted from pure language instruction to the integration of mastering both language for professional communication and the content matter of professional disciplines. (Snow, Met, and Genesee, 1989; Spanos, 1990).

WebQuests are activities specially suited to content-based language learning. Students perform a real world task using authentic materials related to a topic within their academic discipline (Maria, 2002). According to Pérez Torres (2005), WebQuests are activities that meet the requirements of the three essential conditions for language learning "exposure, use and motivation". March (1997) supports the point as saying that "the pedagogical principles of a WebQuest are to assign small groups of students with a challenging inquiry, provide access to an abundance of online resources, and scaffold the learning process to promote higher order thinking".

WebQuests can meet the four criteria for content-based activities below:

1. Learning activities should provide more than one perspective on the content area. This is met by WebQuests, which offer a large number of Web pages with information on different aspects of a topic (Marco, 2002).

2. Activities should present authentic content without oversimplifying it (Spiro and Jehng, 1990).

3. Activities should incorporate visuals and other aids for making associations, since that facilitates deeper thinking (Craik and Lockhart, 1972). The Web pages used in WebQuests contain not only text, but also pictures, sound, and even animation.

4. Activities should encourage the SQ3R formula: surveying, questioning, reading, recalling, and reviewing materials under study (Schmeck, 1986).

Generally speaking, WebQuests are rooted to constructivist, inquiry-based, project-based learning, and content-based language learning approaches (Hopkins-Moore and Fowler, 2002; Matejka, 2004) since they seek student motivation and authenticity, they develop higher thinking skills and promote cooperative learning (Watson 1999; Hopkins-Moore \& Fowler, 2002). 


\section{RESEARCH METHODOLOGY}

\section{A. Participants}

44 second-year students (from among a population of 247 second-year students), 26 females and 18 males, who were attending the third course of reading (reading 3) at the Faculty of English Linguistics and Literature of the University of Social Sciences and Humanities in Ho Chi Minh City (USSH-HCMC) were invited to participate in this newly-designed WebQuest-based reading course. The average age was 20.21 years ranging from 19 to 25 years old. The reason for this selection was their extensive history of reading experience. Freshmen's too brief history of reading experience will probably limit in-depth exploration. Moreover, freshmen's reading reluctance due to their struggle in dealing with English vocabulary and grammar patterns can be miscontrued as their poor reading skill.

\section{B. Instruments}

The instruments include pretest, posttest, and questionnaire helped to collate quantitative data. Each of these instruments was used at different phases of the study and for different purposes: pretest and posttest were taken by 44 students involved in the study right before and after the Web-based course in order to measure the improvement in their reading skill; and the questionnaire was designed online 10 days after the course to investigate the students' attitudes towards the course.

\section{Method}

The method used in the study is action research. Action research is also called a practitioner research. Action research is done by practitioners within a particular situation and will influence what is happening. According to Ferrance (2000, p. 1), action research "specifically refers to a disciplined inquiry done by a teacher with the intent that the researcher will inform and change his or her practices in the future" and "is carried within the context of the teacher's environment - that is, with the students and at the school in which the teacher works - on questions that deal with educational matters at hand." The researcher's perspective therefore is different from that of the external researcher, who stands outside the situation, records observations about it, checks his or her interpretations with participants (McNiff at al., 2003).

An action research lends itself to a spiral of cycles, with the researcher reflecting on each stage of the process (Alberta Teacher Association, 2000). Kemmis (1985) has developed a simple model of the cyclical nature of the typical action research process as the loop of planning, acting, observing, and reflecting, as displayed in Figure 1.

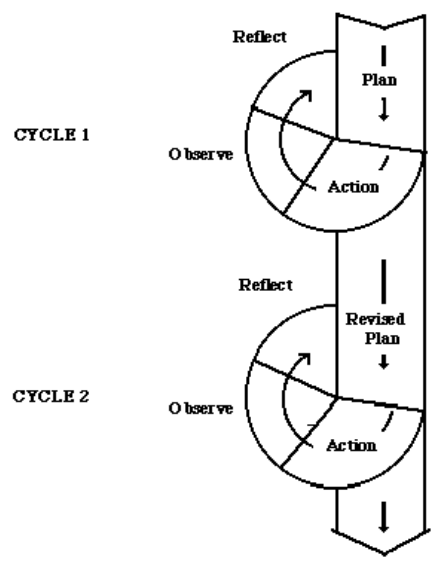

Figure 1. Action research protocol after Kemmis

\section{FINDINGS AND DISCUSSION}

\section{A. The Effect of the Use of WebQuest in the Reading Course on the Students' Reading Competence}

The effect of the newly Web-based reading course on the students was determined through the comparison of the test scores before and after the treatment. The paired sample t-test was administered to test the null hypothesis that "there was no significant difference between the results of pretest and posttest."

TABLE 2.

COMPARISON OF THE PRETEST SCORE AND POSTTEST SCORE

\begin{tabular}{llllll}
\multicolumn{5}{c}{ COMPARISON OF THE PRETEST SCORE AND POSTTEST SCORE } \\
\hline & Mean & $\mathrm{N}$ & Std. Deviation & Std. Error Mean & Sig. (2- tailed) \\
\hline Pretest & 29.77 & 44 & 5.665 & 1.208 & \\
Posttest & 41.91 & 44 & 6.838 & 1.458 & .002 \\
Pretest & & & & & .2 \\
-Posttest & & & & & \\
\hline
\end{tabular}


The findings from Table 2 indicates that across all 44 subjects, the subjects' scores improved, by 12.14 points (41.91 - 29.77) after 14 weeks of applying WebQuest on the teaching of reading. Since the significance value for change in scores is less than 0.01 , the results from the posttest proved the effect of WebQuest in the teaching of reading.

\section{B. Students' Attitude towards the WebQuest-based Teaching of Reading}

The online questionnaire was delivered to 44 students right after the course. The link for the free online survey http://www.surveymonkey.com/s/W7G23JQ was exposed in an email message and sent to all these students. The students could also easily access the online survey by clicking the hyperlink online survey in the WebQuest and answering all the questions provided, both close-ended and open-ended questions. The researcher received 40 (90.91\%) responses from the participants.

\begin{tabular}{|c|c|c|c|c|c|c|c|}
\hline STATEMENTS & $\begin{array}{l}\text { Strongly } \\
\text { Agree }\end{array}$ & Agree & No opinion & Disagree & $\begin{array}{l}\text { Strongly } \\
\text { Disagree }\end{array}$ & $\begin{array}{l}\text { Rating } \\
\text { Average }\end{array}$ & $\begin{array}{l}\text { Response } \\
\text { Count }\end{array}$ \\
\hline $\begin{array}{l}\text { 1. Learning with WebQuest } \\
\text { was useful and interesting }\end{array}$ & $20.0 \%$ & $80.0 \%$ & $0.0 \%$ & $0.0 \%$ & $0.0 \%$ & 1.80 & 40 \\
\hline
\end{tabular}

Responses to Question 1 reveal a positive number as it was strongly supported by $100 \%$ students taking the online survey. This number includes $20 \%$ strongly agreeing and the vast majority (80\%) agreeing that learning with WebQuest was useful and interesting.

\begin{tabular}{|l|l|l|l|l|l|l|}
\hline $\begin{array}{l}\text { 2. The WebQuest was } \\
\text { well-designed. }\end{array}$ & $30.0 \%$ & $45.0 \%$ & $25.0 \%$ & $0.0 \%$ & $0.0 \%$ & 1.95 \\
\hline
\end{tabular}

Question 2 was used to explore the students' opinions on the design of the WebQuest. The responses show that most of the students $(75 \%)$ agreed it was well-designed; while $25 \%$ of the students revealed no idea and no one expressed negative attitude towards the WebQuest.

\begin{tabular}{|l|l|l|l|l|l|l|l|}
\hline $\begin{array}{l}\text { 3. The WebQuest was rich } \\
\text { in content with useful links. }\end{array}$ & $45.0 \%$ & $35.0 \%$ & $20.0 \%$ & $0.0 \%$ & $0.0 \%$ & 1.75 & 40 \\
\hline
\end{tabular}

As regards the content of the WebQuest, in response to Question 3, 80\% of the participants appreciated the rich content and the useful links in the WebQuest while the rest had no view on this.

\begin{tabular}{|l|l|l|l|l|l|l|}
\hline $\begin{array}{l}\text { 4. I prefer learning this Web-based reading course } \\
\text { rather than the traditional paper-based reading course. }\end{array}$ & $35.0 \%$ & $60.0 \%$ & $5.0 \%$ & $0.0 \%$ & $0.0 \%$ & 1.70 \\
\hline
\end{tabular}

Question 4 aimed to ask students to make a comparison between the learning of this Web-based reading course with the traditional paper-based reading course. Virtually all of the students (95\%) revealed that they liked this newly-experienced way of reading learning more than the traditional paper-based one.

\begin{tabular}{l}
$\begin{array}{l}\text { 5. I prefer to choose my own topic } \\
\text { for the weekly presentation. }\end{array}$ \\
\hline
\end{tabular}

In response to Question 5, the majority of students expressed that they prefered choosing the topic by themselves for each weekly presentation to being given by the teacher.

\begin{tabular}{|l|l|l|l|l|l|l|l|}
\hline $\begin{array}{l}\text { 6. Through this Web-based reading } \\
\text { course, my reading skill has improved. }\end{array}$ & $25.0 \%$ & $55.0 \%$ & $15.0 \%$ & $5.0 \%$ & $0.0 \%$ & 2.00 & 40 \\
\hline
\end{tabular}

Question 6 was designed to investigate the students' self-evaluation of the reading skill after the Web-based course. A great percentage of students $(80 \%)$ admitted that their reading skill has been strengthened, whereas $15 \%$ were not aware of the improvement.

\begin{tabular}{|l|l|l|l|l|l|l|l|l|l|l|l|l|l|}
\hline $\begin{array}{l}\text { 7. Through this Web-based reading course, my vocabulary } \\
\text { has been enriched considerably. }\end{array}$ & $40.0 \%$ & $40.0 \%$ & $15.0 \%$ & $5.0 \%$ & $0.0 \%$ & 1.85 & 40 \\
\hline
\end{tabular}


As regards the students' progress in vocabulary, responses to Question 7 reveal a strong agreement (80\%) to the considerable enrichment of vocabulary. $15 \%$ were reluctant to have a definite answer to this question, and merely $5 \%$ showed their negative opinion on this issue.

\begin{tabular}{|l|l|l|l|l|l|l|l|}
\hline $\begin{array}{l}\text { 8. The WebQuest has motivated } \\
\text { me to read further. }\end{array}$ & $45.0 \%$ & $30.0 \%$ & $15.0 \%$ & $10.0 \%$ & $0.0 \%$ & 1.90 & 40 \\
\hline
\end{tabular}

To evaluate the students' motivation brought by the Web-based activities, Question 8 was delivered. In fact, cooperation in doing weekly worksheets in WebQuest motivated a high percentage of students $(75 \%)$ rather than force them to read further. $15 \%$ were not sure about this and $10 \%$ disagreed. The figures generally prove that most of the students had strong motivation in learning with the Web-based course.

\begin{tabular}{|l|l|l|l|l|l|l|l|}
\hline $\begin{array}{l}\text { 9. I have learnt nothing through this } \\
\text { Web-based reading course. }\end{array}$ & $0.0 \%$ & $5.0 \%$ & $10.0 \%$ & $40.0 \%$ & $45.0 \%$ & 4.25 & 40 \\
\hline
\end{tabular}

Question 9 asked students if they had learnt nothing through this Web-based reading course, 85 disagreed and strongly disagreed with the statement, which means that they appreciated the course; $10 \%$ had no idea and only $5 \%$ agreed that they had learned nothing.

\begin{tabular}{|l|l|l|l|l|l|l|l|}
\hline $\begin{array}{l}\text { 10. In general, I was satisfied with } \\
\text { this Web-based reading course. }\end{array}$ & $30.0 \%$ & $55.0 \%$ & $15.0 \%$ & $0.0 \%$ & $0.0 \%$ & 1.85 & 40 \\
\hline
\end{tabular}

Question 10 was geared to decide whether the students were satisfied with the use of WebQuest in the reading program. The data showed that the overall program was supportively rated by the students. A vast majority of the students $(85 \%)$ agreed that they were generally satisfied. Only $15 \%$ of the students did not show their opinions on this. This proved that the WebQuest-based reading program was successful.

The open-ended question 11 explored whether or not the students had any other comments and/or ideas on the use of the Web in this reading program. Only 8 responses were collected as displayed in Table 3.

TABLE 3.

STUDENTS' RESPONSES TO THE OPEN-ENDED QUESTION 11 IN THE QUESTIONNAIRE

\begin{tabular}{|c|c|c|}
\hline \multicolumn{3}{|c|}{$\begin{array}{l}\text { 11. If you have any other comments and/or ideas on the use of the Web in this reading program, write in } \\
\text { the box below. }\end{array}$} \\
\hline answered question & 8 & 8 \\
\hline \multirow[t]{2}{*}{ skipped question } & & 12 \\
\hline & & $\begin{array}{l}\text { Response } \\
\text { Count }\end{array}$ \\
\hline$P_{\text {Hide replies }}$ & & 8 \\
\hline $\begin{array}{l}\text { 1. the time for the course should be longer so that my reading would improve } \\
\text { more. }\end{array}$ & $\begin{array}{l}\text { Wed, May 12, } \\
\text { 2010 9:20 PM }\end{array}$ & Find... \\
\hline 2. i expect to have more comments on the weekly translation from the teacher & $\begin{array}{l}\text { Wed, May 12, } \\
\text { 2010 9:06 PM }\end{array}$ & , $\quad$ Find... \\
\hline 3. This may be the most interesting English course I've ever experienced. & $\begin{array}{l}\text { Wed, May 12, } \\
\text { 2010 8:59 PM }\end{array}$ & , $\quad$ Find... \\
\hline $\begin{array}{l}\text { 4. learning with this Web-based reading course was interesting but not easy at } \\
\text { all }\end{array}$ & $\begin{array}{l}\text { Wed, May 12, } \\
\text { 2010 8:48 PM }\end{array}$ & , $\quad$ Find... \\
\hline $\begin{array}{l}\text { The time for this reading course was so short but we really enjoyed learning } \\
\text { 5. with it. We're expecting to learn with other WebQuest-based programs for } \\
\text { different subjects. }\end{array}$ & $\begin{array}{l}\text { Wed, May 12, } \\
20103: 14 \text { PM }\end{array}$ & 2, 8 \\
\hline $\begin{array}{l}\text { 6. i had a really good time with this course. It, however, was a bit challenging } \\
\text { for us }\end{array}$ & $\begin{array}{l}\text { Mon, May 10, } \\
\text { 2010 8:09 PM }\end{array}$ & Find... \\
\hline $\begin{array}{l}\text { 7. What a very good program. i wish i could have chance to learn other subjects } \\
\text { in a similar way }\end{array}$ & $\begin{array}{l}\text { Mon, May 10, } \\
20107: 58 \mathrm{PM}\end{array}$ & $\begin{array}{l}\text { P } \\
\text { Find... }\end{array}$ \\
\hline $\begin{array}{l}\text { 8. Personally I think the Web-based reading program was really wonderful. I've } \\
\text { learnt a lot of things through this course. We had a good time together as well. }\end{array}$ & $\begin{array}{l}\text { Mon, May 10, } \\
2010 \text { 7:52 PM }\end{array}$ & $Q_{F i}$ \\
\hline
\end{tabular}


TABLE 4.

STUDENTS' RESPONSES TO QUESTIONS 12 \& 13 IN THE QUESTIONNAIRE

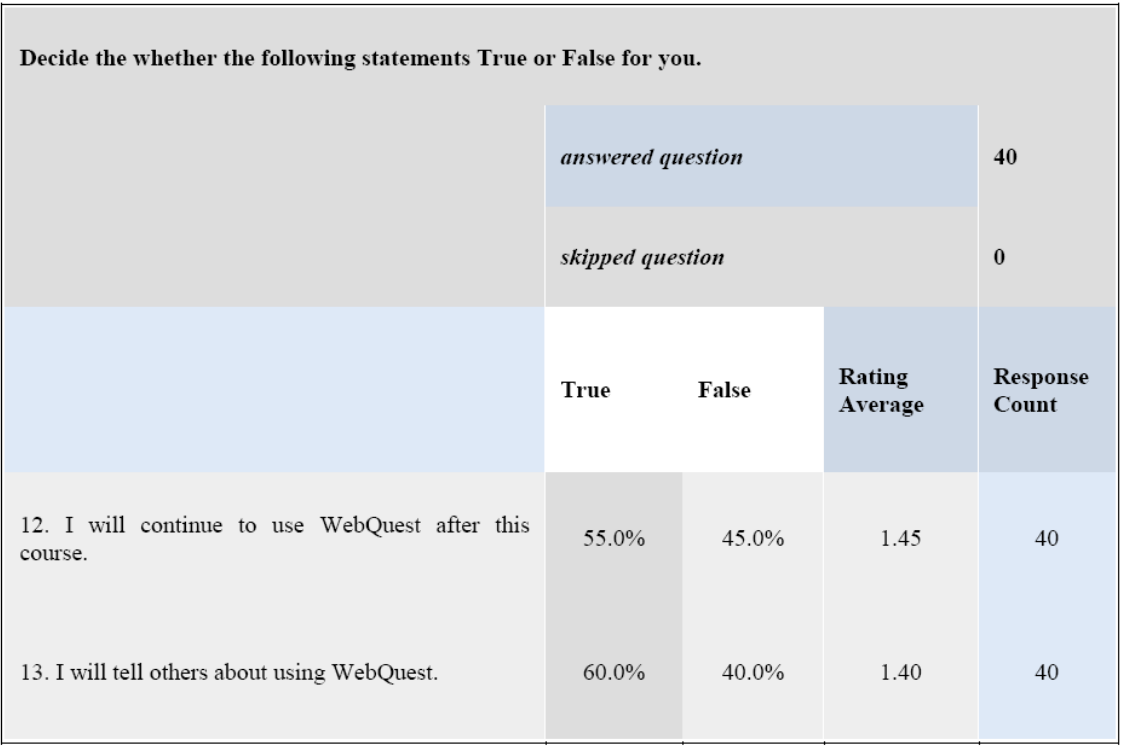

Question 12 is aimed at checking whether the students would continue to use WebQuest to improve their English even when the course has finished. As indicated in Table 4, over half of the students (55\%) agreed that they would continue and the rest (45\%) thought they would stop. This figure implies that, to a certain extent, the Web-based reading course had positive impact on the students' learning activities.

Question 13 is raised to ask if the students would tell others about using WebQuest in learning English, 60\% agreed while $40 \%$ disagreed with this point. This fact proves that a number of the students realized the advantages that the WebQuest brought to them.

The data analysis of the pretest and posttest scores the responses to the online questionnaire survey prove that the students not only significantly improved their reading skill but also had positive attitude towards the implementation of the Web-based reading programs.

\section{CONCLUSION}

The use of WebQuest has been discussed and practised in the world of EFL teaching for several years. However, the utilization of this Web-based tool in a reading course still has been a new experience to EFL teachers in the context of Vietnam.

The study was geared to investigate whether the utilization of WebQuest helps improve reading skill, and to explore the students' attitude towards WebQuest-based teaching of reading. The findings reveal that the students who received the WebQuest-based program made considerable improvement in their reading. The findings were also enhanced by the positive feedback of the students towards the use of WebQuest through the online survey carried out after the course.

This research provides an implication that WebQuests can promote the teaching of reading. Additionally, this Web-based tool enables teachers to share their own materials and provides free access to a multitude of resources in different disciplines at different language levels. WebQuest appears as a suitable integrated way to immerse the students in a real professional in which to carry out a whole project involving technology.

\section{REFERENCES}

[1] Alberta Teachers' Association. (2000). Action research guide for Alberta teachers. Edmonton, AB: Author.

[2] Alexander, I.C., and Elena A.D. (2005). The breakthrough of the Internet to Empower ESP Teaching and Learning at Tomsk Polytechnic University. Global Journal of English Education, Australia.

[3] Autodesk Foundation (1998). Sixth annual PBL conference. Retrieved from http://www.autodesk.com/foundation.

[4] Baccarini, D. (2004). The implementation of authentic activities for learning: A case study. In Seeking Educational Excellence. Proceedings of the 13th Annual Teaching Learning Forum, 9-10 February 2004. Perth: Murdoch University. Retrieved May 20, 2009 from: http://lsn.curtin.edu.au/tlf/tlf2004/baccarini.html.

[5] Bamford, J. (2000). Annotated bibliography of works on Extensive Reading in a second language. Reading in a Foreign Language.

[6] Blasszauer, J. (2003). WebQuests: blending learning philosophy and practice. Novelty-A journal of English Language Teaching and Cultural Studies in Hungary, pp. 1-12.

[7] Bruce, B. (2004). Developing and Implementing extensive reading within a reading program. Retrieved December 19, 2007 from: http://cicero.u-bunkyo.ac.jp/lib/kiyo/fsell2004/index.html.

[8] Bruner, J. (1990). Acts of meaning. Cambridge, MA: Harvard University Press. 
[9] Charupan, S., Soranastaporn, S., \& Suwattananand, N. (2001). The Use of the Internet for ELT in Thai Public Universities. SLLT: Studies of Language and Language Teaching, 2.

[10] Craik, F.I.M., \& Lockhart R.S. (1972). Levels of processing: A framework for memory research. Journal of Verbal Learning and Verbal Behavior.

[11] Day, R.R. \& Bamford, J. (1998). Extensive Reading in the Second Language Classroom. Cambridge: Cambridge University Press.

[12] Dodge, B. (2001). Focus: Five rules for writing a great WebQuest. Learning \& Leading with Technology, 28(8). Retrieved June 10, 2008 from: http://www.webquest.futuro.usp.br/artigos/textos outros-bernie1.html.

[13] Dudeney, G., \& Hockly, N. (2007). How to teach English with Technology. Educational Technology \& Society. Pearson.

[14] Ferrance, E. (2000). Action Research. Themes in Education. Northeast and Islands Regional Educational Laboratory At Brown University.

[15] Grabe, W., \& Stoller, F. (2002). Teaching and researching reading: Applied linguistics in action. New York: Longman.

[16] Grant, M. (2002). Getting a grip on project-based learning: theory, cases and recommendations. Meridian: A Middle School Computer Technologies Journal, 5(1). Retrieved December 30, 2008 from: http://www.ncsu.edu/meridian/win2002/514/index.html.

[17] Haarman, L., et al. (1988). Reading Skills for the Social Science. Oxford: Oxford University.

[18] Hafiz, F. M., \& Tudor, I. (1989). Extensive reading and the development of language skills. ELT Journal, 43(1), 4-13.

[19] Hopkins-Moore, B., \& Fowler, S. (2002). WebQuests: changing the way we teach online. Paper presented at the CHI2002 conference in Minneapolis, MN. Available from: http://www.hopkins-moore.com/webquests.html.

[20] Kasper, L. (2000). New technologies, new literacies: Focus discipline research and ESL learning communities. Language Learning and Technology, 4, 2, pp. 105-128. Retrieved on April 1, 2002 from http: llt.msu.edu/vol4num2/kasper/default.html.

[21] Kimball, J. (1997). Concept-acquisition: Tapping the Internet for ideas. JALT96 Conference Proceedings. Retrieved April 1, 2002 from the World Wide Web: http://www.fauxpress.com/kimball/res/concept.htm.

[22] Kumari, S. (1998). Teaching with the Internet. Journal of Information Technology for Teacher Education, 7 (3), pp. 363-377.

[23] Mak, L. (1995). Language learning of a new kind. Retrieved on April 1, 2009 from the World Wide Web: www.hku.hk/ssrc/newLearn.html.

[24] March, T. (1997). Working the Web for education: Theory and practice on integrating the Web for learning. Retrieved March 10, 2008 from the World Wide Web: http://www.ozline.com/learning/theory.html.

[25] March, T. (2008). What WebQuests are (Really). Retrieved 15 August, 2009 from http://bestwebquests.com/what_webquests_are.asp.

[26] Marco, M. (2002). Internet Content-Based Activities for ESP. English Teaching Forum, 40(3), pp. 20-25.

[27] Maria, José Luzón Marco (Spain). (2002). Internet Content-Based Activities for English for Specific Purposes. English Teaching Forum Magazine, January 2002, Volume 40, Number 3.

[28] Mary, B. (1998). Constructivism and Technology on the Road to Student-Centered Learning. Tap into Learning-Technology Assistance Program 1(1). Austin, Texas. Retrieved 29 September, 2007 from http://www.sedl.org/pubs/tapinto/v1n1.pdf.

[29] Matejka, D. (2004). Project-Based learning in online postgraduate education. Journal of Issues in Informing Science and Information Technology, Vol. 1. Retrieved February 28, 2010 from: http://articles.iisit.org/073matej.pdf.

[30] Matusevich, M.N. (1995). School Reform: What Role can Technology Play in a Constructivist Setting? Retrieved January 20, 2009 from: http://pixel.cs.vt.edu/edu/fis/techcons.html.

[31] McCabe, M. (1998). Lesson from the Field: Computer conferencing in higher education. Journal of Information Technology for Teacher Education, 7 (1), pp. 71-84.

[32] McNiff, J., Lomax, P., \& Whitehead, J. (2003). You and your action research project. 2nd ed. London: Routledge.

[33] Nuttall, C. (1996). Teaching reading skills in a foreign language. Oxford: Heinemann English Language Teaching. Chapter 8: An extensive reading programme, pp. 127-148.

[34] Palmer, H.E. (1921). Principles of language-study. London: Harrap. (Reissued in 1964 by Oxford University Press).

[35] Paran, A. (2003). Intensive reading. English Teaching professional, 28.

[36] Phirie, D., Tsimanyana, Olga M.S., and Masendu, M. E., (2000). The reading process. The commonwealth of Learning, Vancouver, BC V6H 3 X8 Canada.

[37] Reeves, T.C., Herrington, J., \& Oliver, R. (2002). Authentic activities and online learning. In A. Goody, J. Herrington \& M. Northcote (Eds.), Quality conversations: Research and Development in Higher Education, Volume 25, pp. 562-567. Jamison, ACT: HERDSA. Retrieved December 30, 2008 from: http://www.ecu.edu.au/conferences/herdsa/main/papers/ref/pdf/Reeves.pdf

[38] Pérez Torres, M.I. (2005). Diseño de Webquests para la Enseñanza/Aprendizaje del Inglés como Lengua Extranjera: Aplicaciones en la Adquisición de Vocabulario y la Destreza Lectora. Granada: Servicios Editoriales de la Universidad de Granada.

[39] Schmeck, R.R. (1986). Learning styles and learning strategies. New York: Plenum.

[40] Snow, M. A., Met, M., \& Genesee, F. (1989). A conceptual framework for the integration of languages and content in second/foreign language instruction. TESOL Quarterly, 23, 201-217.

[41] Spanos, G. (1990). On the integration of language and content instruction. Annual Review of Applied Linguistics, 10, $227-240$.

[42] Spiro, R.J., \& Jehng, J. (1990). Cognitive flexibility and hypertext: Theory and technology for the non-linear and multidimensional traversal of complex subject matter. In Nix, D., \& Spiro, R. (eds.), Cognition, Education, and Multimedia. Hillsdale, NJ: Erlbaum.

[43] Warschauer, M. (1996). Motivational aspects of using computers for writing and communications. In Warschauer, M. (ed.), Telecollaboration in foreign language learning. Honolulu, HI: Second Language Teaching and Curriculum Center, University of Hawaii Press. Retrieved on April 1, 2010 from the www.nflrc.hawaii.edu/NetWorks/NW01/)

[44] Warschauer, M. (1999). Electronic literacies: Language, Culture, and power in online education. Mahwah, NJ: Lawrence Erlbaum Associates. 
[45] Warschauer, M., H. Shetzer \& C. Meloni. (2000). Internet for English Teaching. Alexandria, VA: TESOL Publications.

[46] Watson, M. et. al. (1999). CDP cooperative learning: Working together to construct social, ethical and intellectual understanding. In Sharan, S. (ed). Cooperative Learning Methods, pp. 137-156. Westport, CT: Praeger Publishers.

[47] Welch, R. (1997). Introducing extensive reading. The Language Teacher, 21 (5), pp. 51-53.

Luu Trong Tuan is currently an EFL teacher at National University of Ho Chi Minh City. He received his M.TESOL from Victoria University, Australia in 2004. Besides his focus on TESOL, his recent publications such as Language Transfer is Cultural Transfer between Communities, Social Sciences Review, No. 11, 2004, pp. 60-63; and Principles for Scientific Translation, Social Sciences Review, No. 8, 2004, pp. 63-67; and Building Vietnamese Medical Terminology via Language Contact, Australian Journal of Linguistics, Vol. 29, No. 3, September 2009, pp. 315-336 show his interest in language contact and translation areas. 